\title{
Use of Patent Applications as a Tool for Technology Development Investigations on Ethanol Production from Lignocellulosic Biomass in Brazil
}

\author{
Luiz André Felizardo Silva Schlittler',Adelaide Maria de Souza Antunes, ${ }^{182}$, Nei Pereira Junior'
}

\begin{abstract}
The growing concerns regarding the future of global energy supplies have encouraged R\&D in alternative sources to complement the global energy matrix. Brazil has earned notoriety as one of the largest producers of ethanol and biomass. This has aroused other countries' interest in Brazil's capabilities. However, the technologies for converting biomass into ethanol are not sufficiently mature, and have been developed in a decentralized manner. The lignocellulosic ethanol technologies can be divided into the following three groups: pretreatment, enzymes and ethanol production. One of the most efficient methods for mapping such technologies is through patent applications because the applications provide important information on trends in long-term technological development. Among all the patent applications deposited in the Brazilian database, pretreatment technologies were the most exploited followed by enzymes and ethanol production. The large number of documents from USA and European countries efforts the importance of Brazil in this technological scenario.
\end{abstract}

Keywords: ethanol; lignocellulosic biomass; patent applications.

\footnotetext{
'School of Chemical - Federal University of Rio de Janeiro. Graduate Course on Technology of Biochemical and Chemical Processes. Av. Horácio Macedo, 2030. Technology Center. ZIP CODE: 2194I-909, Brazil. Phone: +552125627644. Email: las@betal-4.com.br and nei@ eq.ufrj.br.

${ }^{2}$ INPI - Brazilian National Institute of Industrial Property. Praça Mauá, 7 - Centro. Rio de Janeiro, RJ - CEP 2008I-240, Brazil. Tel. +5521303732 I I. Email: adelaide@inpi.gov.br.
} 


\section{Introduction}

Social development and long distance locomotion in the modern world increasingly require more energy. The expected reduction in oil reserves and the rising cost of producing oil, coupled with growing concerns over environmental preservation, demand immediate solutions for the effects that already define societies' way of life. This movement opposing fossil source exploitation discontinues a global paradigm, which has been sustained for decades and was the basis for developing an entire industry.

Various forms of renewable energy, especially biofuels, began to stand out in the world energy matrix. However, another issue that concerns humanity is the dichotomy between the availability of land for growing food and biofuel production. Several discussions about the use of land for energy production and its impact on the future availability of food, in light of an increasing world population, are now prominent among the scientific community and policy makers.

Residual biomass plays an important role once it does not compete with the use of land for food production. Agricultural waste is a valuable source for producing biofuels and different compounds with a wide range of values. Therefore, there is growing interest in developing biotechnologies that convert abundant solid wastes into fuels, primarily ethanol and molecules from cellulose- and hemicellulose-derived carbohydrates. Research institutions around the world have been studying different routes for treating these materials and developing microorganisms with enhanced productivity. Brazil has raised particular interest because of its leading position in the world as a producer of sugar cane and its respective commodities (alcohol and sugar), as well as industrial structure that generates millions of tons of bagasse every year. Most bagasse is consumed in boilers as a fuel for heat and power production at industrial sites. Nevertheless, considerable levels of bagasse remain as a surplus, which requires appropriate use and creates a friendly environment for research, development and innovation directed toward using this abundant feedstock.

As an important player in the ethanol industry and, because of the features that support Brazil as a potential hub for implementation of new technologies, global companies seek to protect their technologies in this country. Thus, this article aims to describe Brazil's import in this context by mapping the patent applications for the production of ethanol and establishing the levels of significance and technology maturity of the country.

\section{Lignocellulosic Biomass Generation in Brazil}

In tropical countries, the natural substitute for oil is biomass. Biomass is defined as any renewable organic matter, including plant material, grown either on land or in water, manure and/or animal products, byproducts of food processing, forestry and waste. Several possible sources can generate biomass; the most common source is residues generated in agribusiness activities. Biomass can also be produced from dedicated bioenergy crops (Schuchardt et al., 200I).

There is a formal market for residual biomass in Brazil. The sugar/ethanol industry is the most developed model for biomass use, particularly sugar cane bagasse. Bagasse is used as a source of supplementary food for cattle (Pedroso et al., 2010), to produce electricity/heat and as a raw material for producing cellulose pulp and paper. However, even with all the possibilities, energy production exceeds consumption; thus, biomass waste is an environmental problem.

Brazil has a growing capacity for generating residual biomass because it has exceeded its limit for grain production each year.According to the Brazilian Ministry of Agriculture, Livestock and Supply (MAPA, 20II), in 2010 the country cultivated approximately $6 \mathrm{I}$ million hectares. The main crops were sugar cane, soybeans, corn, cassava and rice, which occupied a combined 50 million hectares with a total production of 933 million tons. It was estimated that approximately 463 million tons of residual biomass were generated. However, approximately 100 million hectares of farmlands are still available.

\section{Ethanol Production in Brazil}

Ethanol production in Brazil has always been connected with sugar cane, which was introduced to the country in 1533, three decades after its discovery. Initially, the cane industry was focused on sugar production and ethanol was a byproduct. In 1975, through incentive policies created to stimulate the national alcohol industry (PROALCOOL), the most competitive industrial structure developed in the world.

In 2010, the Ministry of Agriculture, Livestock and Supply established 426 of the units for processing cane sugar in operation during the $2009 / 10$ harvesting period, which spread across 22 states. Among these units, 16 were dedicated exclusively to sugar production, 249 units to both products (ethanol and sugar) and $\mathrm{I} 6 \mathrm{I}$ exclusively to ethanol.

At the end of the $2009 / 10$ harvesting period, approximately 26 million cubic meters of ethanol were produced. However, the Ministry of Agriculture projected a demand of 58 million cubic meters in 2019. Thus, production must increase $120 \%$ over the next eight years; lignocellulosic biomass is

ISSN: 07I 8-2724. (http://www.jotmi.org)

Journal of Technology Management \& Innovation (C) Universidad Alberto Hurtado, Facultad de Economía y Negocios. 
important because it can support this demand without land expansion for sugar cane cultivation.

\section{Ethanol Production from Lignocellulosic Biomass}

Ethanol production from lignocellulosic biomass is emerging as a sustainable alternative for renewable energy production (Sukumaran et al., 2009). Recent technologies have facilitated the use of lignocellulosic materials for ethanol production. These technologies are complex and require great investment in capital and research.There are several ways to describe such processes with peculiarities that differentiate these processes and render them more or less attractive depending on the regional characteristics.

In general, such processes can be described through two common steps. The first is pretreatment, and the second is conversion. Pretreatment comprises operations that transform the material into a suitable form for the conversion step. Four primary strategies convert biomass into ethanol, and certain strategies require enzymes, particularly cellulase, to hydrolyze the cellulose structure. This hydrolysis reaction renders biomass more susceptible to fermenting microorganisms. The conversion step involves agents, such as yeasts and bacteria, that convert sugars into ethanol. Figure I shows a summary block diagram of the technologies' core.

The four strategies for biomass conversion into ethanol, as mentioned above, combine the primary operations (pretreatment, transformation and enzymatic production) in different structures of processing, separately or simultaneously. Genetic engineering has been intensely used as a tool for the newest strategies to facilitate overall integration of operations.

The first strategy is "Separate Hydrolysis and Fermentation" (SHF) in which the biomass is pretreated and con- verted in separate stages. The hemicellulose and cellulose fractions are converted separately, and the latter fraction is hydrolyzed enzymatically followed by fermentation. The second strategy is "Simultaneous Saccharification and Fermentation" (SSF), and the main differences between SSF and $\mathrm{SHF}$ is the use of enzymes to hydrolyze cellulose simultaneously with fermentation. The third strategy, "Simultaneous Saccharification and Co-Fermentation" (SSCF), is a relatively recent strategy in which the sugars from both fractions are converted by a single microorganism. For ethanol, no natural microorganism can execute it efficiently, and molecular biology techniques are necessary. The latter strategy, "Consolidated Bioprocess" (CBP), is the most advanced in which co-fermentation and enzyme production are performed by a single microorganism. The SSCF and CBP strategies are entirely dependent on genetic techniques.

The concept of deriving ethanol from lignocellulosic materials is not new, but it was neglected for decades. Brazil has had experience with these techniques; it has been researching these methods since the 1970s and has experimented with different processes on different scales from the bench to demonstration units. Currently, ethanol from residual biomass is widely studied, and there is a global effort to develop commercial technology that uses biomass for alcohol production.

The Brazilian government, which is interested in dominating this arena, has been fueling such research in its country through capital funding and other incentives to establish productive partnerships among industry, educational and P\&D\&I institutions. By December of 2010 , the primary funding agencies launched 23 financing calls, which have provided over US $\$ 1.00$ billion to develop research topics involving residual biomass and biofuels.

Large companies, such as Petrobras, Dow Chemical, Oxite-

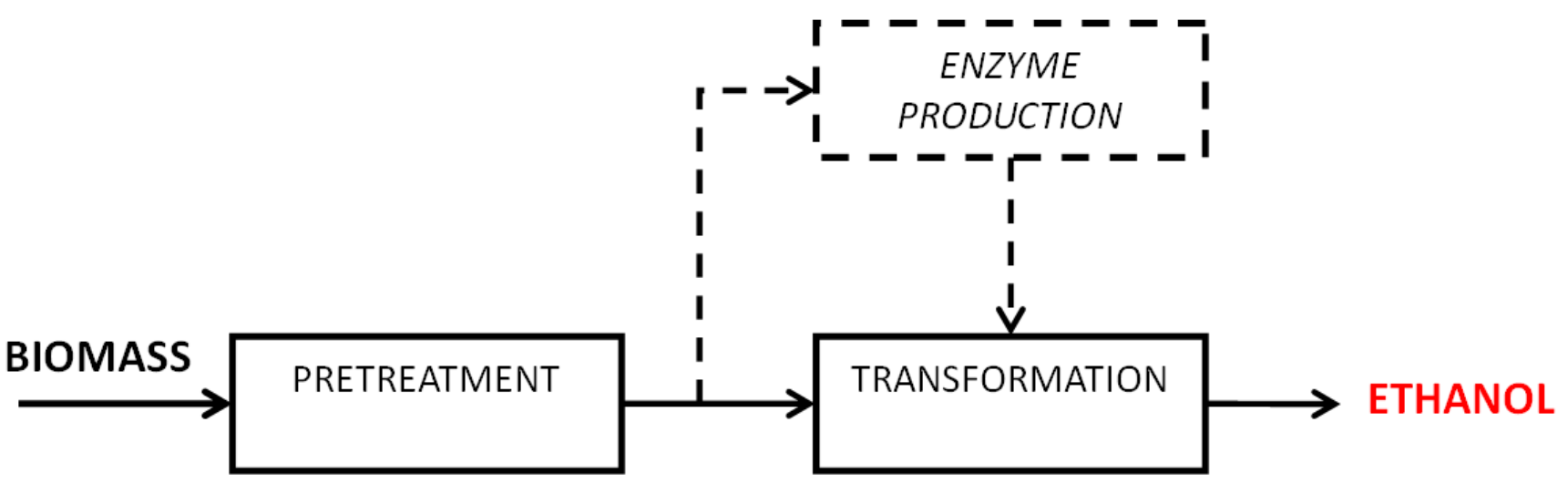

Figure I. Summary schematic for the production of ethanol from lignocellulosic biomass.

ISSN: 07 I8-2724. (http://www.jotmi.org)

Journal of Technology Management \& Innovation (C) Universidad Alberto Hurtado, Facultad de Economía y Negocios. 
no, Suzano, Braskem, Fibria, Cosan and Klabin, have shown interest in investing in this sector and have begun to communicate with centers of excellence in Brazil. A division of scientific efforts is concentrated in Rio de Janeiro and São Paulo.

\section{Method}

It is known that patent documents contain relevant information on technologies (Araújo, 1984; Cabral, 1999) and proper analysis of these documents aids in identifying technological indicators to establish government programs (Demuner et al.; 20II). Thus, the Brazilian patent office (INPI) database was searched to identify the status quo of the country in the lignocellulosic ethanol production using the patent applications deposited through 2009.

This investigation involved the acquisition of information such as the nationality of the applicant, the application's nature, priority date and associated international patent classifications, as well as the title of the technology. This investigation was aimed at mapping the protected information in Brazil and, consequently, analyzing its import on a global scale.

Ethanol production was divided into three parts: pretreatment, lignocellulase enzymes and ethanol production from cellulosic biomass. The patent searches were performed through the primary classifications linked with keywords. For the pretreatment group, the primary classification was $\mathrm{Cl} 3 \mathrm{~K} \mathrm{I} / 02$; for the enzymes, it was $\mathrm{Cl} 2 \mathrm{~N} \mathrm{9/42}$; and for the production group, they were $\mathrm{Cl} 2 \mathrm{P} 7 / 08$ and $\mathrm{Cl} 2 \mathrm{P} 7 / 10$ .The information was organized in an MS-Excel spreadsheet and analyzed using Vantage Point version 5.0 software.

\section{Results and Discussion}

\section{I. Pretreatments}

Pretreatments are a series of operations that are applied to lignocellulosic materials and can break the bonds that unite macro-structures in molecules. These operations transform the raw material into a form available to microorganism conversion. These operations can be classified as physical, physico-chemical, chemical and biological in accordance with the agent used.

The first patent application registered in the INPI base related to pretreatment methods for cellulosic biomass was at the end of the 1970s. During the 1980s, there was relatively intense technology protection activity in Brazil, which decreased in the following decades. Between 1978 and 2009, 149 relevant patent applications were identified, as shown in Figure 02.

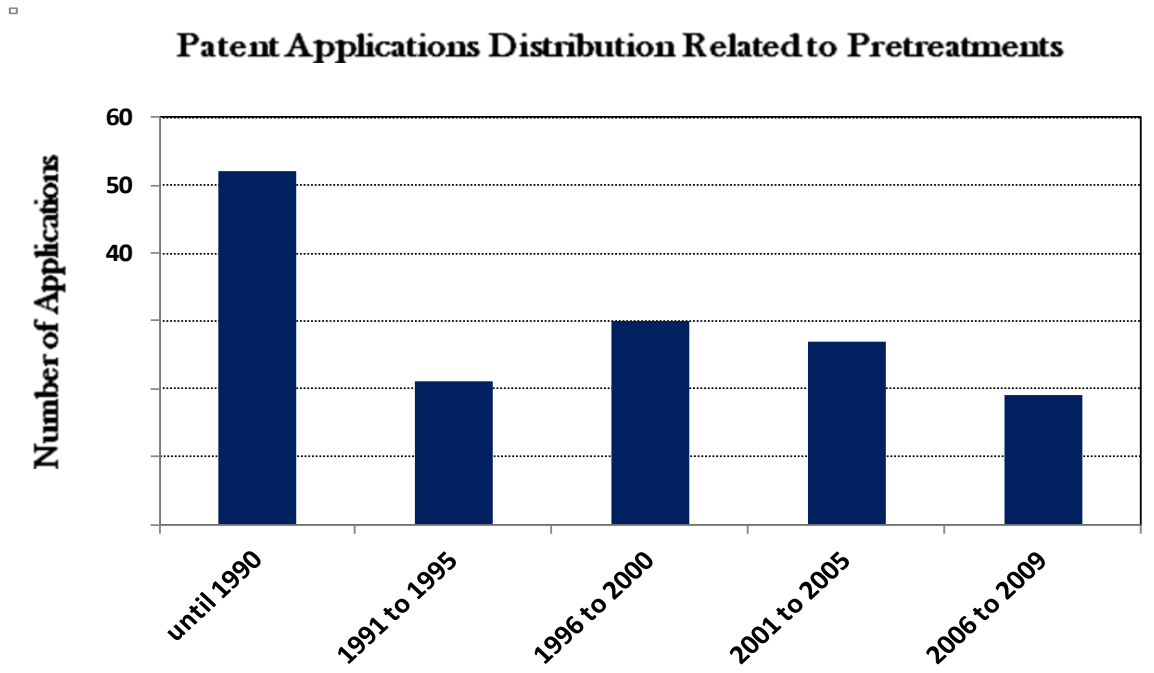

Figure 2. Temporal distribution of patent applications related to pretreatment operations.

\footnotetext{
'CI3K I/02: Saccharides other than sucrose generated from natural sources or hydrolysis of naturally occurring di-, oligo- or polysaccharides produced through saccharification of cellulosic materials.

${ }^{2} \mathrm{Cl} 2 \mathrm{~N}$ 9/42: Enzymes; compositions containing enzymes or proenzymes; processes for preparing, activating, inhibiting, separating or purifying enzymes that act on beta-I, 4-glucosidic bonds (e.g., cellulase).

${ }^{3} \mathrm{CI} 2 \mathrm{P}$ 7/08: Fermentation: ethanol produced as by-product or from waste or cellulosic material substrates.

${ }^{4} \mathrm{CI}$ P 7/I0: Fermentation: ethanol produced from substrates containing cellulosic material.
}

ISSN: 07 I8-2724. (http://www.jotmi.org) 
During the 1990s, most of the relevant applications related to pretreatment applied to the pulp and paper industry processes. This observation is corroborated by the subclass D2IC domain associated with the group C08B I/00.This result is due to economic stimuli that have been applied in research and development since the early 1970s for cellulose production from various raw material sources, which culminated with the global consolidation of this sector.

Among the applications deposited in the early 1980s, observations on the subclass $\mathrm{CI} 3 \mathrm{~K}$ suggest that its technologies initiated the development of methods for saccharification of cellulosic materials. It was observed that association of these subclasses with $\mathrm{CI} 2 \mathrm{P}$ was simultaneous and was the birth of "lignocellulosic ethanol" in Brazil. Figure 3 shows the most frequent subclasses among the pretreatment applications (with at least 10 occurrences).

Subclass A23K indicates that certain developments were focused on the animal food industry. Today, a specific market involves sugar cane fibers as a complementary source for cattle feed. Lignocellulosic fibers pretreated by processes such as steam explosion improves ruminant digestion, which accelerates mass gain. However, despite having the largest herd of cattle in the world, there is not a developed logistic system that uses residual biomass to supply the entire animal feeding industry, which justifies the efforts and investments applied to development of pretreatments linked to conversion processes such as ethanol.

In origin, the United States is the highest ranked country for most patents applications deposited in the Brazilian patent office (INPI), with $38 \%$ of all applications; the United States is followed by Brazil and Germany with 13\% and $9 \%$ of all applications, respectively. Considering the various regions, the American continent is responsible for $54 \%$ of all applications, followed by Europe and Asia.The profiles for the institutions differ considerably between Brazil and the rest of the countries, as shown in Figure 4.

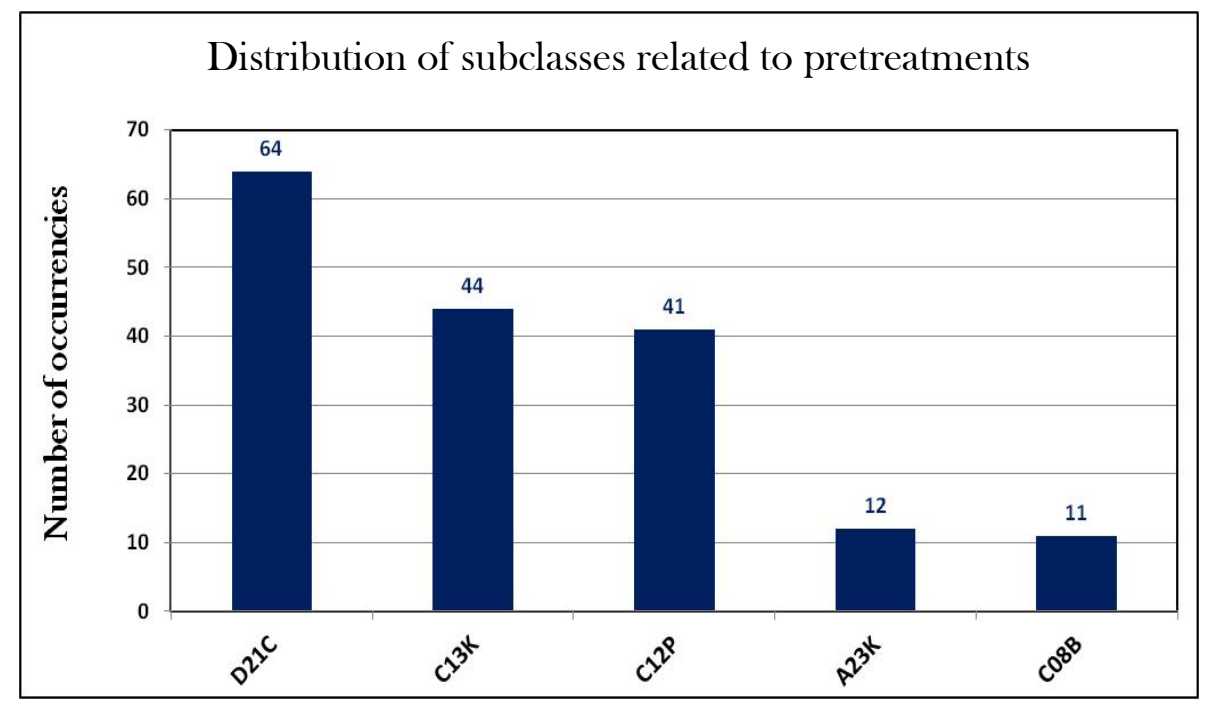

Figure 3. Subclass distribution among the patent applications related to pretreatment processes.

D2 IC: Production of cellulose by removing non-cellulose substances from cellulose-containing materials; regeneration of pulping liquors, apparatus thereof. CI3K: Saccharides other than sucrose produced by natural sources or hydrolysis of naturally occurring di-, olig- or polysaccharides. CI2P: Fermentation or enzymatic processes for synthesizing a desired chemical compound or composition or to separate optical isomers from a racemic mixture.A23K: Feedstuffs especially adapted for animals; methods especially adapted for production thereof. C08B: Polysaccharides; derivate thereof.

${ }^{5}$ D2 IC: Production of cellulose by removing non-cellulose substances from cellulose-containing materials; regeneration of pulping liquors, apparatus thereof.

${ }^{6} \mathrm{C} 08 \mathrm{~B}$ I/00: Polysaccharides; derivate thereof; and preparatory treatment of cellulose, which generates derivates thereof.

${ }^{7} \mathrm{CI} 3 \mathrm{~K}$ : Saccharides, other than sucrose, generated from natural sources or by hydrolysis of naturally occurring di-, olig- or polysaccharides. ${ }^{8} \mathrm{Cl}$ P: Fermentation or enzyme-using processes to synthesize a desired chemical compound or composition or to separate optical isomers from a racemic mixture.

${ }^{9} \mathrm{~A} 23 \mathrm{~K}$ : Feedstuffs especially adapted for animals; methods especially adapted for production thereof.

ISSN: 07 I8-2724. (http://www.jotmi.org)

Journal of Technology Management \& Innovation (C) Universidad Alberto Hurtado, Facultad de Economía y Negocios. 


\section{Patent applications related to pretreatment in terms of origin and nature of the applicants}

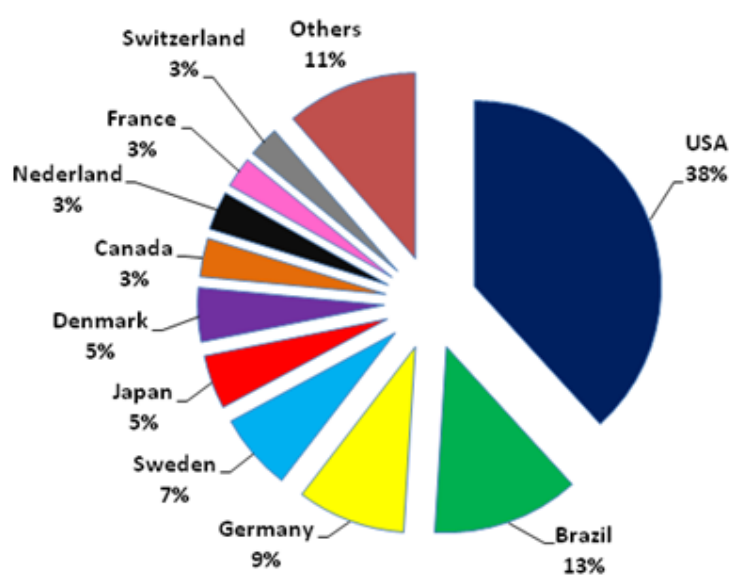

(a) Origin

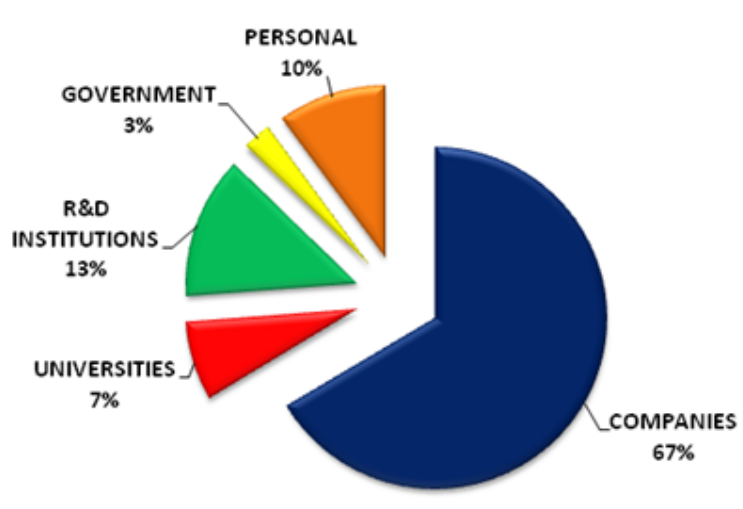

(b) Nature

Figure 2.Temporal distribution of patent applications related to pretreatment operations.

In general, companies were responsible for $67 \%$ of the deposits, followed by research and development institutions with 13\%. However, for the Brazilian applicants, the companies were not the largest depositors. Of the 19 patent applications, 10 were deposited by universities, research institutes and individuals. The close relationship among individuals, universities and R\&D\&l institutions should be noted, and they can be considered as a single institution. This behavior is related to the profile for the scientific activities in the country, which is concentrated in educational and R\&D institutions supported by government incentives, with little explored by private companies until recently.

Considering titularity, 89 applicants comprise the 149 documents; thus, the distribution is considerably heterogeneous. Six institutions stand out, with an average of 4 applications each: Andritz Inc. (US), Midwest Research Operation (US), Purdue Research Institute (US), Metso Paper Sweden AB (SE), Novozymes (DK) and Dedini Indústria de base (BR). It is noteworthy that 15 applications include personal titularity, which corresponds with $10 \%$ of the total number of applications. From these 15 documents, 7 originated in Brazil, which demonstrates the importance of individual scientists in the research and development of pretreatment.

\subsection{Cellulase Production}

Enzymes in the lignocellulosic complex are important inputs in ethanol production from residual biomass. They are responsible for hydrolysis of the fibers and the consequent release of monomeric sugars, which renders them acces- sible to fermenting microorganisms. The primary types of enzymes used for ethanol production are cellulases and $x y-$ lanases, which aid in hydrolyzing cellulose and hemicellulose fractions.

Production of these enzymes uses biomass as raw material, and Brazil is currently an attractive country because it generates significant levels of biomass. In addition, there is a developed consumer market of enzymes, particularly for cellulase. In light of these characteristics, large companies have settled into Brazil, including Novozymes and Genencor. The first patent application registered in the INPI databank and related to enzymes was deposited in 1984, and until 2009, there were 120 applications. Twenty-five years after the first document, the applications were concentrated between 1991 and 2005, perhaps in part because of a Novozymes industrial facility in south Brazil established in 1989. This concentration peaks from 1996 to 2005, as shown in Figure 04. It should also be noted that molecular biology is an important tool for developing microbial strains with a capacity for enhanced enzymatic productivity as well as producing new and improved enzymes.

As mentioned above, $41 \%$ of the applications involve genetic improvements, which is demonstrated by the group $\mathrm{CI} 2 \mathrm{~N}$ $15 / 00$, especially CI2N I5/56, in 34 of the 49 documents. The following most frequent classes are combinations between $\mathrm{Cl} 2 \mathrm{~N} \mathrm{I5/80}-\mathrm{Cl} 2 \mathrm{~N} \mathrm{I5/8I} \quad$ (9 occurrences) and $\mathrm{CI} 2 \mathrm{~N} \mathrm{I5/62}$ - $\mathrm{CI} 2 \mathrm{~N} \mathrm{I5/63}$ (8 occurrences). Thus, there has been a trend toward exploring heterologous expression in fungus, especially in yeasts. Figure 5 shows the percentage 


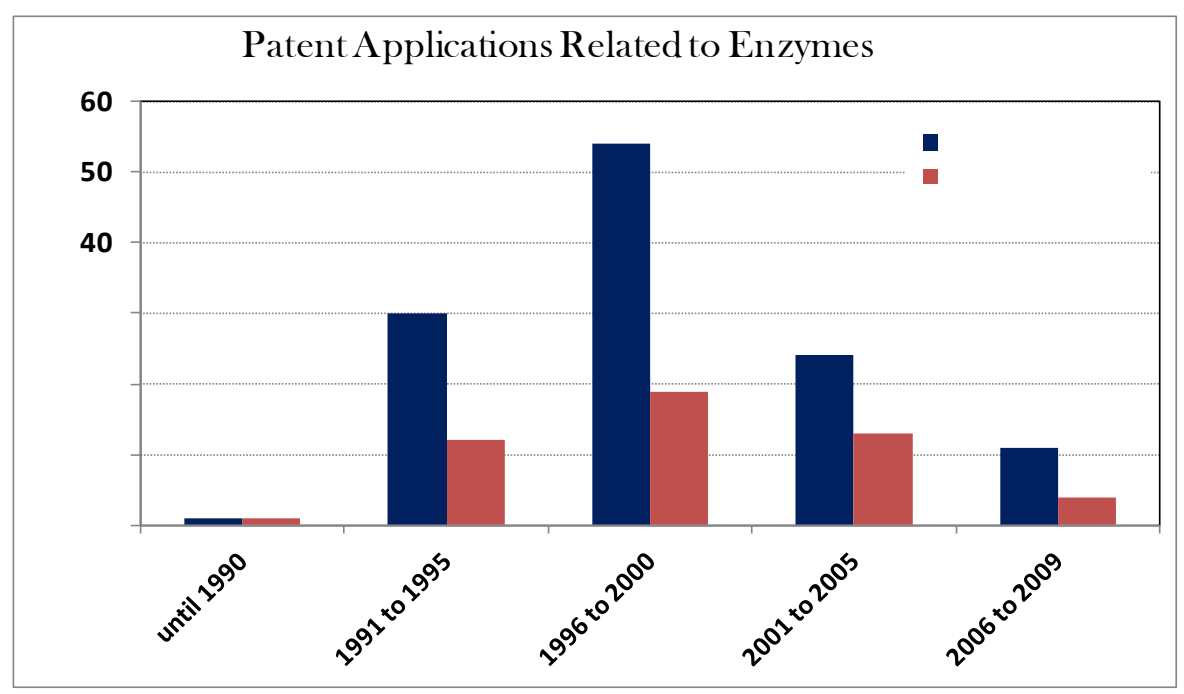

Figure 4.Temporal distribution of patents applications related to lignocellulasic enzymes.

of groups distributed among the class $\mathrm{CI} 2 \mathrm{~N}$ 15/00. According to the pie chart, the nine most frequent groups represent $78 \%$ of the total, and the remaining $22 \%$ comprises 17 groups.

U.S. institutions are the largest depositors in the INPI base with 37 patent applications, followed by Danish depositors with 32. However, for North America, all the applications were deposited by 13 institutions, while the Danish documents were deposited by only 4 institutions. Thus, Danish companies, specifically Novozymes, are world leaders in enzyme production for various industry uses. It is noteworthy that the U.S. companies Genencor and Procter \& Gamble are references in the enzyme field. Figure 6 shows the top countries and largest patent depositors in Brazil.

It should be mentioned that companies such as Novozymes and Genencor have global structures. In other words, they are in several countries and own patents in different countries. For example, Novozymes has submitted patent applications in the USA and Denmark. Simultaneously, Genencor recently merged with Danisco and now the group has patents in several countries. This situation generates controversy regarding the geographical distribution of the technologies because although they are scattered over different countries, they are concentrated in a few organizations. Thus, this distribution creates a false impression of the geographical distribution of technologies.

The institutions' profiles indicate that companies are investing more in research and development, which account for $84 \%$ of the applications, followed by universities and research institutions with $11 \%$ and $5 \%$, respectively. However, the case for Brazilian institutions is the opposite because universities account for $84 \%$ of patent applications, as observed with the pretreatment technologies. However, it is important to highlight the companies, such as Petrobras, that direct considerable capital to research and develop the production of renewable energy, especially ethanol. Petrobras in particular has engaged in a transformation process from an oil to energy company and has prioritized research on cellulase production, which is focused on lignocellulosic-based ethanol production.

The emphasis for enzymes is cellulase, which accounts for most of the documents. The hemicellulase studies are focused on the xylanase, although it corresponds to $20 \%$ of the applications. There has been a great effort to develop processes for producing enzymes associated with ethanol production; the majority of such applications are in the group CI2P 7/00. However, at the same proportion, there are several applications on product protection; these applications comprise mixtures that contain different enzymes (cellulase and xylanase) for producing cellulose pulp, textiles and food. Excluding subclass $\mathrm{CI} 2 \mathrm{~N}$, Figure 7 shows the most frequent subclasses that occur at least 10 times.

\subsection{Ethanol Production from Lignocellulosic Biomass}

The investigation into ethanol production was much simpler compared with the 2 previous cases because ethanol has a specific classification, $\mathrm{CI} 2 \mathrm{P} 7 / 00$. Specifically, ethanol produced from residual lignocellulosic biomass is classified by the groups $\mathrm{Cl} 2 \mathrm{P} 7 / 08$ and $\mathrm{Cl} 2 \mathrm{P} 7 / 10$. However, in several cases, the classes were related to enzymes and pretreatment, as a strategy to reduce costs.

The search generated 90 documents on technologies from 17 different countries and several biomass sources. The first document dates from 1979, and these initial efforts resulted 


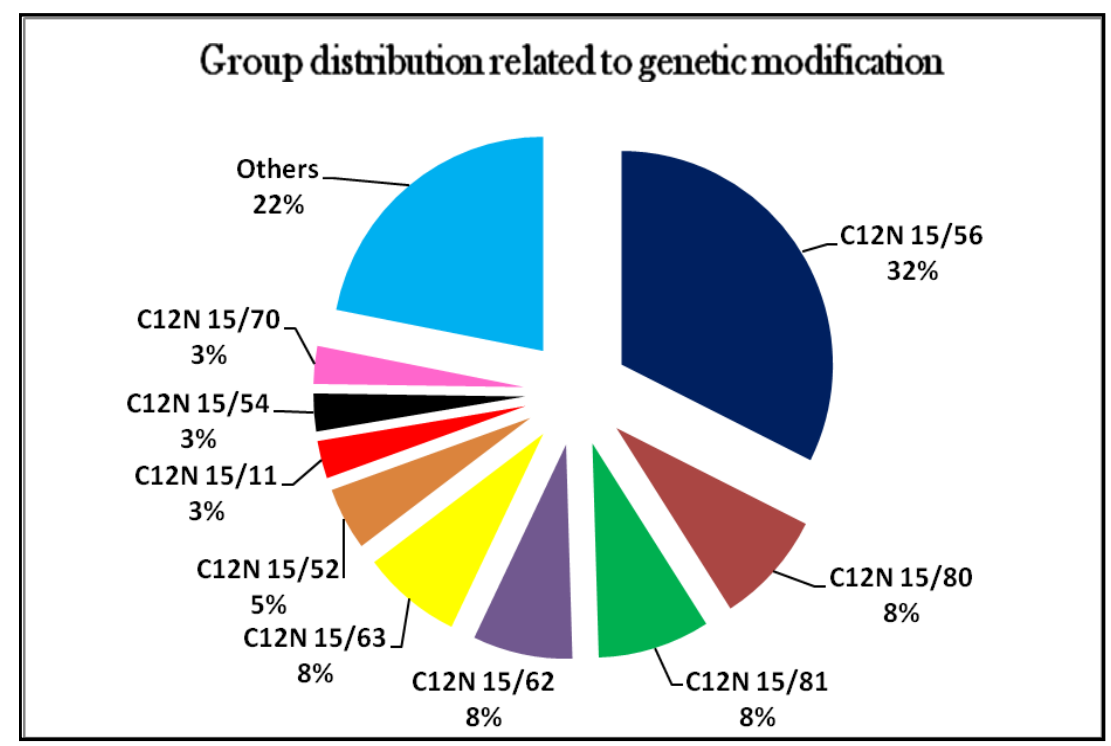

Figure 5. Group distribution related to genetic modification (CI2N 15/00) of enzymes.

$\mathrm{CI}$ N 15/II: DNA or RNA fragments; modified forms thereof. CI2N 15/52: Genes encoding enzymes or proenzymes. CI2N I5/54:

Genes encoding transferases. CI2N 15/56: Genes encoding enzymes or proenzymes that act on glycosyl compounds. CI2N I5/62:

DNA sequences that code for fusion proteins. CI2N 15/63: Introduction of foreign genetic material using vectors; vectors; use of hosts therefore; regulation of expression. CI2N 15/70:Vectors or expression systems especially adapted for E. coli. CI2N 15/80:Vectors or expression systems especially adapted for fungi. CI2N 15/8I:Vectors or expression systems especially adapted for yeasts.

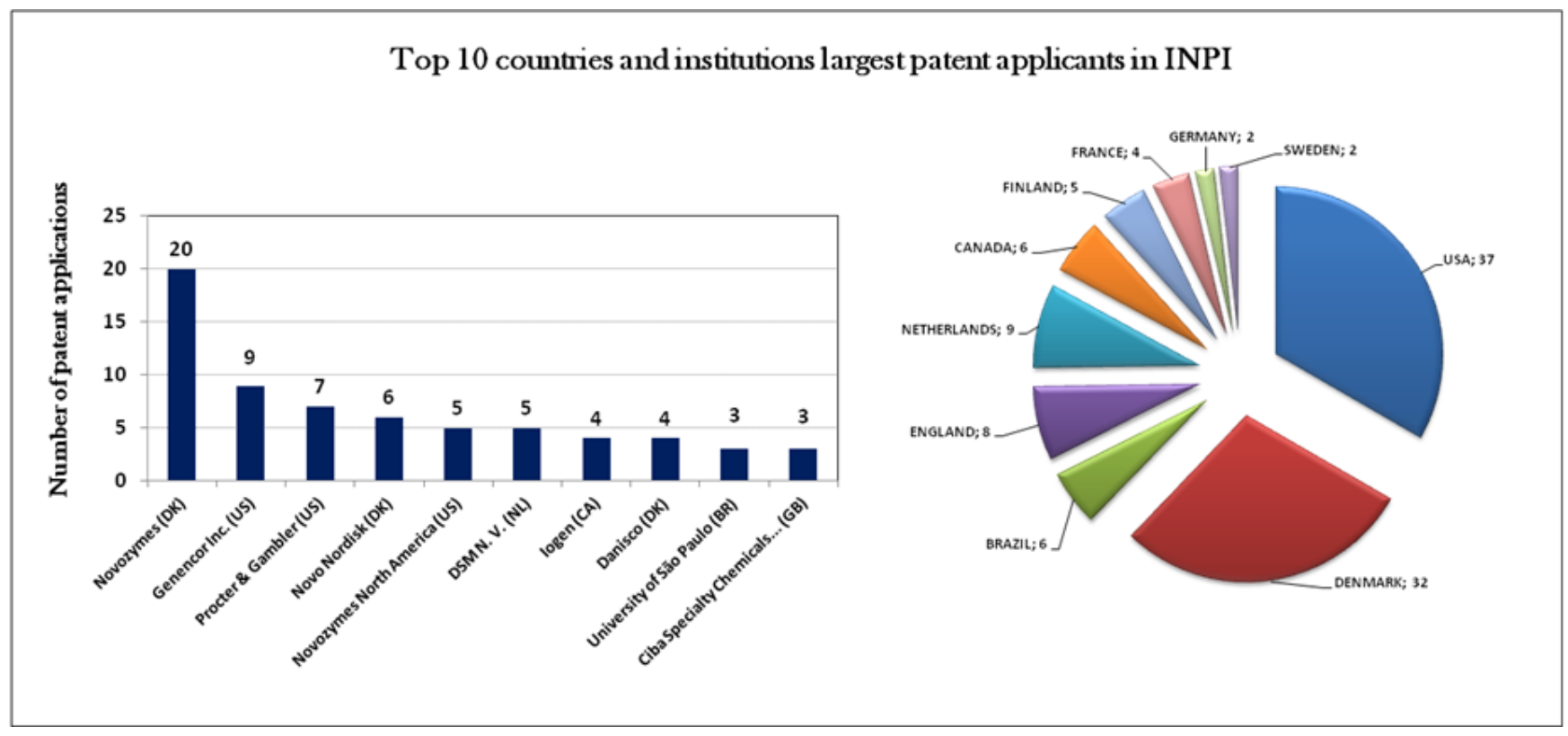

Figure 6. Top ten countries and institutions that are the largest patent applicants in the INPI on cellulosic enzymes

${ }^{10} \mathrm{CI}$ N 15/00: Mutation or genetic engineering; DNA or RNA concerning genetic engineering, vectors (e.g., plasmids, or their isolation, preparation or purification).

${ }^{11} \mathrm{Cl} 2 \mathrm{~N} \mathrm{15/56:} \mathrm{Genes} \mathrm{encoding} \mathrm{for} \mathrm{enzymes} \mathrm{or} \mathrm{proenzymes} \mathrm{that} \mathrm{act} \mathrm{on} \mathrm{glycosyl} \mathrm{compounds.}$

${ }^{12} \mathrm{CI} 2 \mathrm{~N} \mathrm{15/80:Vectors} \mathrm{or} \mathrm{expression} \mathrm{systems} \mathrm{especially} \mathrm{adapted} \mathrm{for} \mathrm{fungi.}$

${ }^{13} \mathrm{CI} 2 \mathrm{~N} \mathrm{15/81:Vectors} \mathrm{or} \mathrm{expression} \mathrm{systems} \mathrm{especially} \mathrm{adapted} \mathrm{for} \mathrm{yeasts.}$

${ }^{14} \mathrm{CI} 2 \mathrm{~N} \mathrm{15/62:} \mathrm{DNA} \mathrm{sequences} \mathrm{that} \mathrm{code} \mathrm{for} \mathrm{fusion} \mathrm{proteins.}$

${ }^{15} \mathrm{CI} 2 \mathrm{~N} \mathrm{15/63:} \mathrm{Introduction} \mathrm{of} \mathrm{foreign} \mathrm{genetic} \mathrm{material} \mathrm{using} \mathrm{vectors;} \mathrm{vectors;} \mathrm{use} \mathrm{of} \mathrm{hosts} \mathrm{therefore;} \mathrm{regulation} \mathrm{of} \mathrm{expression.}$

ISSN: 07 I8-2724. (http://www.jotmi.org)

Journal of Technology Management \& Innovation (c) Universidad Alberto Hurtado, Facultad de Economía y Negocios. 


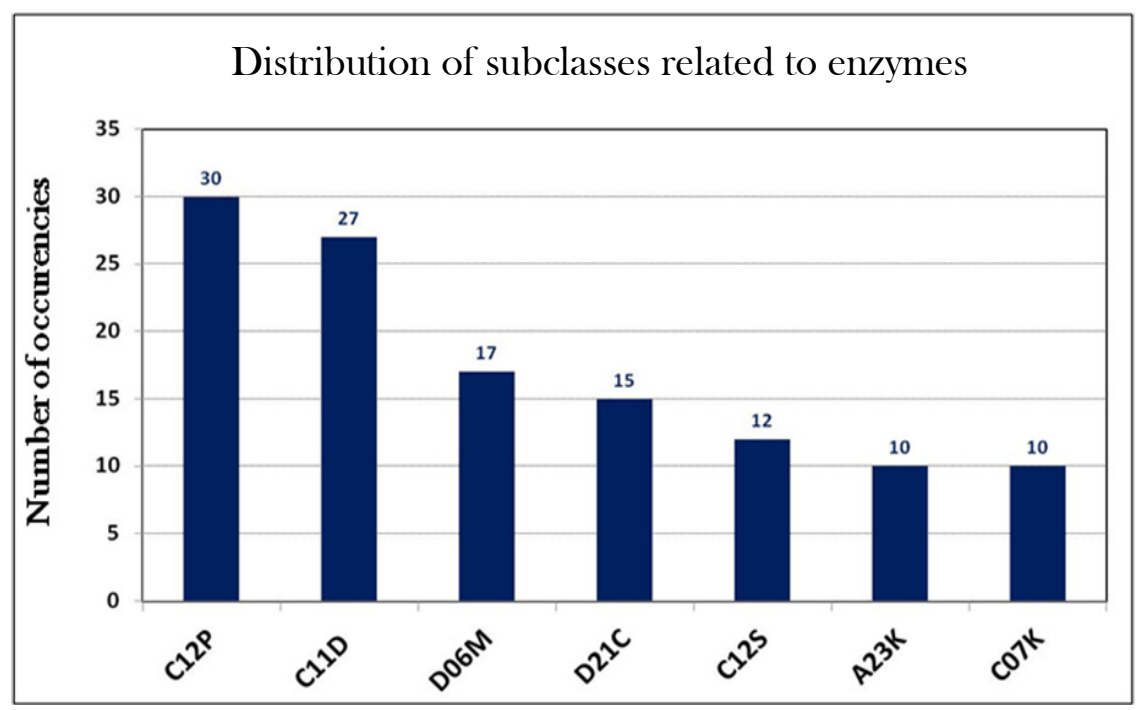

Figure 7. Subclasses with higher frequencies among the patent applications related to enzymes.

CI2P: Fermentation or enzymatic processes to synthesize a desired chemical compound or composition or to separate optical isomers from a racemic mixture. CIID: Detergent composition; D06M:Treatment of fibers, yarns, threads, fabrics, feathers or fibrous goods made from such materials. D2IC: Production of cellulose by removing non-cellulosic substances from cellulose containing materials. CI2S: Processes using enzymes or microorganisms to treat textiles or to clean solid surface materials. A23K: Feedstuffs especially adapted for animals; methods especially adapted for production thereof. C07K: Peptides.

from the National Alcohol Program incentives created by the government in 1975 because biomass residues were and still are a concern for the ethanol industry.

The temporal distribution of the patent applications for ethanol production is different from pretreatment and enzymes. Shown in Figure 8, the activity of technological protection decreases after 1990 and intensifies beginning in $200 \mathrm{I}$. In fact, research on biomass for energy production has gained notoriety beginning in the late 1990s with increased concerns over traditional energy sources. Due to the importance of Brazil in a global ethanol scenario, institutional interest in protecting their technologies in Brazil was expected.

Only for ethanol production does Brazil have more patent applications in the INPI than the United States. However, these two countries compose $68 \%$ of the applications, which is expected because they are the two largest global ethanol producers. The global profile of the institutions is the same because most of such efforts are concentrated in these companies; this is true for Brazil, and currently, Brazil's role in ethanol production differs from its role in pretreatment and enzymes, as shown in Figure 9.

Globally, 60 large projects are centered on conversion of biomass to ethanol; certain projects have advanced to involve small and medium scale units. Among these projects, little more than half are in operation under management of over 30 companies. The remainder are in the planning phase or under construction.
The pioneer for this technological movement in Brazil is the industrial organization Dedini Industria de Base located in São Paulo state, which has developed a process for hydrolysis with concentrated acid, "Dedini Fast Hydrolysis," run on a demonstration scale. Nevertheless, large petroleum companies such as Petrobras have recently begun researching technologies for ethanol production from residual biomass. Petrobras entered the international market of companies operating its own pilot units to establish a set of technologies to generate biofuels as a commercial reality. Moreover, the company is the first in Latin America to develop a technology based on diluted acid pretreatment followed by enzymatic cellulose hydrolysis.

The Brazilian government, which is interested in mastering this subject, is stimulating R\&D\&l efforts in Brazil through capital funding for the establishment of productive partnerships between industry, universities and research institutes. Until August 2009, the primary funding agencies had launched 17 announcements to support development programs for issues involving residual biomass and biofuels, and they provided R\$942 million ( USD 523 million). Under this technological growth scenario, 17 countries have concerns over protecting technologies in Brazil, as shown in Figure 9. Excluding the subclass $\mathrm{CI} 2 \mathrm{P}$, subclass $\mathrm{CI} 2 \mathrm{~N}$, especially $\mathrm{CI} 2 \mathrm{~N}$

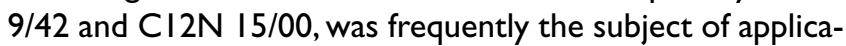
tions. Thus, the trend for ethanol production is associated with enzymatic hydrolysis, which generates several technical and economic challenges. As with the enzymes, genetic tools have been applied to promote positive results. The enhanced 


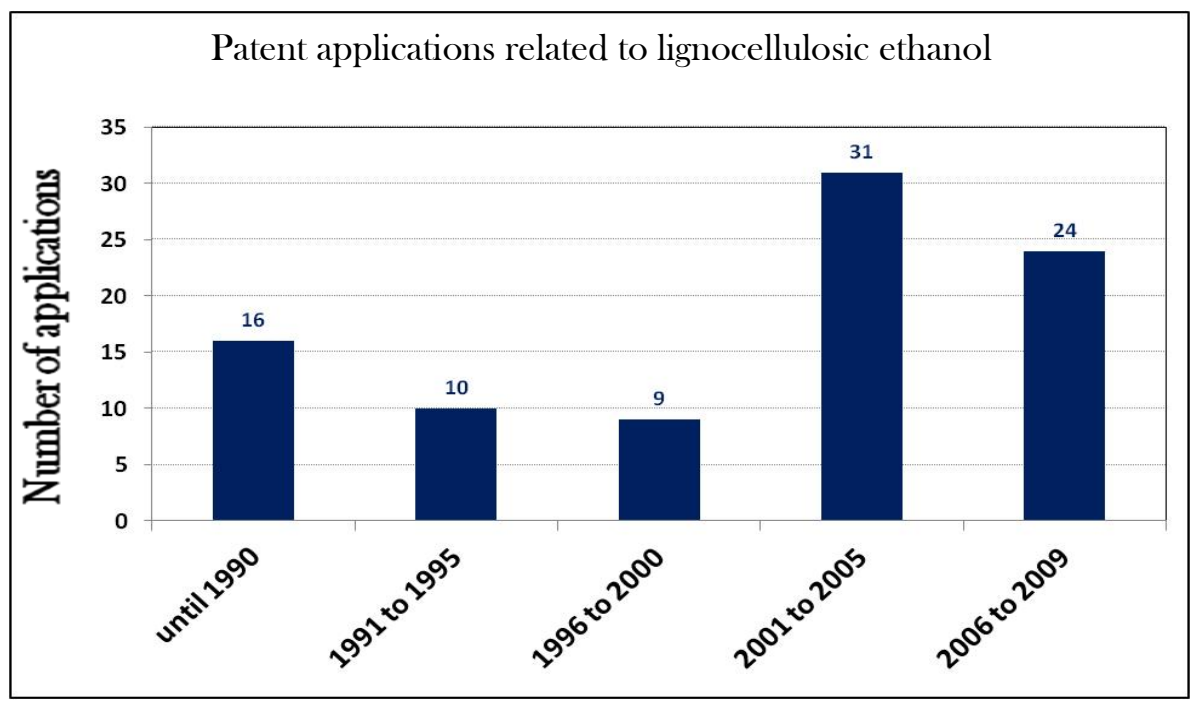

Figure 8.Temporal distribution of patents applications related to lignocellulosic-based ethanol production.

Patent Application related to lignocellulosic to ethanol in terms of origin of the applicant

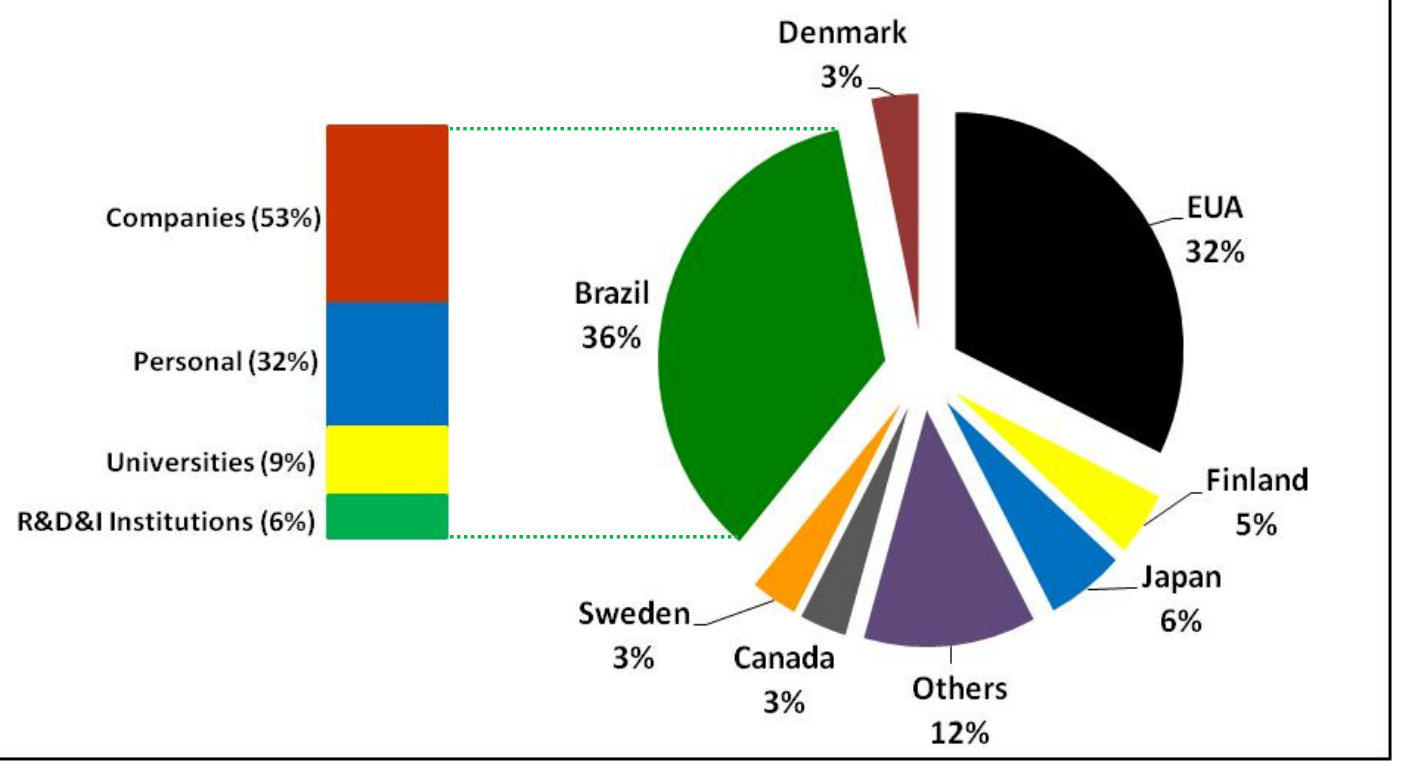

Figure 09. Distribution of patent applications in Brazil for lignocellulosic-based ethanol conversion with the origin and nature of the applicant.

frequency of subclass $\mathrm{CI} 3 \mathrm{~K}$ indicates that despite the effort on enzymatic processing, pretreatment is essential for ethanol production.

For conversion of sugars into ethanol, there is a major focus on yeasts as the conversion agent. In particular, the species Sacharomyces cerevisiae is most common because it is robust and has a high tolerance for substrate and product concentrations. In addition, this is a well-known microorganism in industry and the science community. Nevertheless, despite being a minority, certain bacteria have also gained favor, such as Z. mobilis and E. coli. These bacteria are supported for its considerable capacity for converting glucose into ethanol and the latter through its capacity for genetic manipulation.

\section{Conclusions}

Among 359 patent applications deposited in the INPI database, pretreatment technologies were the most exploited 
followed by enzymes and ethanol production. In general, using a combination of the international patent classifications, the data demonstrate that much of the information on conversion of biomass into ethanol is concentrated in sectors such as textiles, food and chemical specialties.

The largest number of applications deposited in Brazil are from the United States of America, but counties such as Sweden, Finland, Denmark, Germany, Japan, Netherlands and Brazil are considerably important in ethanol production. For the nature of the applicant institutions, companies worldwide have applied greater efforts in research and development on ethanol production with the exception of Brazil, where efforts are more concentrated in universities, especially pretreatment and enzymes.

Brazil has gained notoriety in the academic and scientific communities as well as industrial fields because it has a favorable environment for innovation in the biomass to ethanol technologies. Brazil has the natural conditions to become the largest producer of this new ethanol due to the huge levels of feedstock, the advanced structure of the ethanol industry and, consequently, all of the necessary logistics. Large companies are entering the country, and it is obvious that there will be necessarily more incentives; however, if this technological chain becomes a commercial reality on a large scale, Brazil will be an appropriate place for global corporations with an export platform.

\section{Acknowledgments}

The authors express their gratitude to Flavia Mendes and Rodrigo Cartaxo from SIQUIM-UFRJ for their effort in applying the data mining procedures.

\section{References}

ARAÚJO, V.M.R.H. (2003). Use of the patent information in development countries. Information of Science I3(I), 53-56.

CABRAL, L.L. (1999). How to access and use a technological information in the patent documents. In: II Intellectual Property and Technology Commercialization Meeting. Brazil.

DEMUNER et al. (20II). Technology Prospecting on Enzymes for the Pulp and Paper Industry. Journal of Technology Management \& Innovation. 6(I), p. I 48-I58.

MAPA. (20II). Agroenergia (Estatística). http://www.agricultura.gov.br/desenvolvimento-sustentavel/agroenergia/ estatistica. [Acessed December 20I I].

PEDROSO,A. F et al. (2010). Performance of dairy cows fed rations produced with sugarcane silages treated with additives or fresh sugarcane. Rev. Brasileira de Zootecnia, 39(9), p. 1889-1893.

SCHUCHARDT, U. et al. (200I). The petrochemical industry in the next century: How to replace petroleum as raw material. Química Nova, 24(2), p. 247-25I.

SUKUMARAN, R. K.. et al. (2009). Cellulase production using biomass feed stock and its application in lignocellulose saccharification for bio-ethanol production. Renewable Energy, 34, 42I-424. 